\title{
Barriers to international supply chain management in Iranian flower industry
}

\author{
Arash Riasi* $^{*}$
}

PhD Student, University of Delaware, USA

\begin{tabular}{l}
\hline C H R O N I C L E \\
\hline Article history: \\
Received October 28, 2014 \\
Received in revised format 2 \\
February 2015 \\
Accepted 4 February 2015 \\
Available online \\
February 42015 \\
\hline Keywords: \\
Flower Industry \\
International Supply Chain \\
Management \\
Flower Distribution \\
Distribution Barriers \\
Supply Chain Management \\
Technologies
\end{tabular}

A B S T R A C T

The main purpose of this study was to determine the major barriers to international supply chain management in Iranian flower industry. The results of the research revealed that the most important barrier is lack of investment in Iranian flower distribution sector. The results also indicated that the second most important barrier to international supply chain management in Iranian flower industry might be the rules that limit the presence of international distributors in the country's flower industry. According to this research's findings it can be concluded that it is useful to allow foreign investors to invest in this sector in order to improve the efficiency of supply chains and to ease the introduction of modern supply chain technologies to Iranian flower industry.

Management

Distribution Bar

Supply Chain Managemen

\section{Introduction}

Handfield (2011) defines supply chain management as "the active management of supply chain activities to maximize customer value and achieve a sustainable competitive advantage.” Every prosperous company owes some of its success to effective supply chain management. Supply chain management covers the procurement of raw materials from suppliers and the distribution of finished products to consumers. In today's business environment inventory management, production planning and scheduling, logistics management, and information management are vital to satiating customers' needs and creating competitive advantages. The global supply chain management is one of the most important parts of flower industry, because the distribution of final products of this industry is convoluted. The durability of cut flowers is a major issue in the distribution of these products and requires complicated planning. Iranian flower industry is largely dependent on global markets, because it needs to obtain most of its raw materials from international suppliers and it also sells most of its products to international markets. Experts believe that if the main barriers to international supply chain

*Corresponding author. Tel: +1-302-898-6249 E-mail addresses: riasi@udel.edu (A. Riasi) 
management in Iranian flower industry will be identified and resolved, this industry can gain a big share in global markets (Karimi \& Salehi 1997).

Growth in the agricultural sector is important because it helps to increase food security, to fight against poverty (Eicher \& Staatz, 1998; Montalvo \& Ravallion, 2010; Cervantes-Godoy \& Dewbre, 2010), to contribute to the growth of other parts of the economy (Christiaensen \& Demery, 2007), to preserve natural resources (McCalla \& Nash 2007), to improve income distribution (Ligon \& Sadoulet, 2007), and to decrease unemployment (Mohamadi, 2001; Mellor \& Ranade, 2002); in order to have a highly developed flower industry which is a major sector in a country's agribusiness it is important to identify the barriers against effective supply chain management and to find ways to resolve these barriers. This study intends to identify the main barriers to successful supply chain management in Iranian flower industry.

\section{Iranian Flower Industry}

Iran exports more than 87000 metric tons fresh flowers and 200 million cut flowers each year (Khojaste Nejad 2011). The biggest barriers against Iranian flower industry development are the high usage of traditional flower cultivation methods (Zamanian, 2010) and inefficient distribution channels (Yaghoubi \& Mohamad Rezayi, 2007). Although Iran's flower industry is new in comparison to the world's major flower exporting countries but because of the excellent quality of Iranian flowers and suitable weather condition of the country, this industry has great capabilities for growth. Mazandaran, Isfahan, Tehran, Alborz, and Markazi provinces are the major flower production hubs in Iran. According to Forghaani and Kiaani Abari (2005), Isfahan, Tehran and Markazi provinces have competitive advantage in production of rose, gladiolus and tuberose; this advantage helped cut flower producers in these regions to export more than $75 \%$ of their productions to international markets. In national accounts, export consists of transactions in goods and services (sales, barter, gifts or grants) from residents to non-residents (Lequiller \& Blades, 2006) and flower export can be considered as a potentially thriving source of foreign exchange earnings for a country like Iran (Riasi \& Amiri Aghdaie, 2013). Of particular interest is the role of barriers during the initial stages of the export development process (Leonidou, 1995). Iranian flower industry is currently in its early stages of growth and it needs effective supply chains in order to expand its international trade. Currently the biggest customers of Iranian flowers are the United Arab Emirates, the Netherlands, Iraq, Azerbaijan, Saudi Arabia, Kuwait, Turkmenistan, China, Japan, and Vietnam. (Riasi \& Amiri Aghdaie, 2013).

The reinforcement of the agricultural sector can help Iran to attain self-sufficiency in the production of agricultural products (Amiri Aghdaie et al., 2012) and one of Iran's most prosperous industries that can generate more foreign exchange earnings for the country is the flower industry. Iran's flower exports has increased to a large extent in the last ten years (Razaeii, 2012) which means that there should be an effective international supply chain management in this industry in order to maintain the current positive trend. Transportation is a vital issue in the flower industry, since it helps to connect producers to their customers (Hosseini \& Hajishams, 2012) and suppliers; ineffective transportation is one of the major problems of Iranian flower exporters since they cannot easily export their products to international markets. Although in most parts of the world flowers are exported with the use of special vehicles which have cold storages; Iranian flowers are mostly exported by passenger airplanes (Yaghoubi \& Mohamad Rezayi, 2007) which do not have appropriate conditions for keeping cut flowers in their suitable shape and quality. Hosseini \& Hajishams (2012) believe that in order to retain the quality of exported flowers during the export process, special vehicles should be used for the transportation of Iranian flowers; additionally there should be an effective supply chain in order to exploit Iran’s strategic geographical position and its accessibility to global markets. 


\section{Methodology}

In order to identify the major barriers to international supply chain management in Iranian flower industry, a survey was conducted. Seven senior managers from Iranian flower export companies and flower distribution companies were surveyed. Fig. 1 shows the personal characteristics of these 7 managers. Each of these seven managers introduced one barrier to international supply chain management in Iranian flower industry.

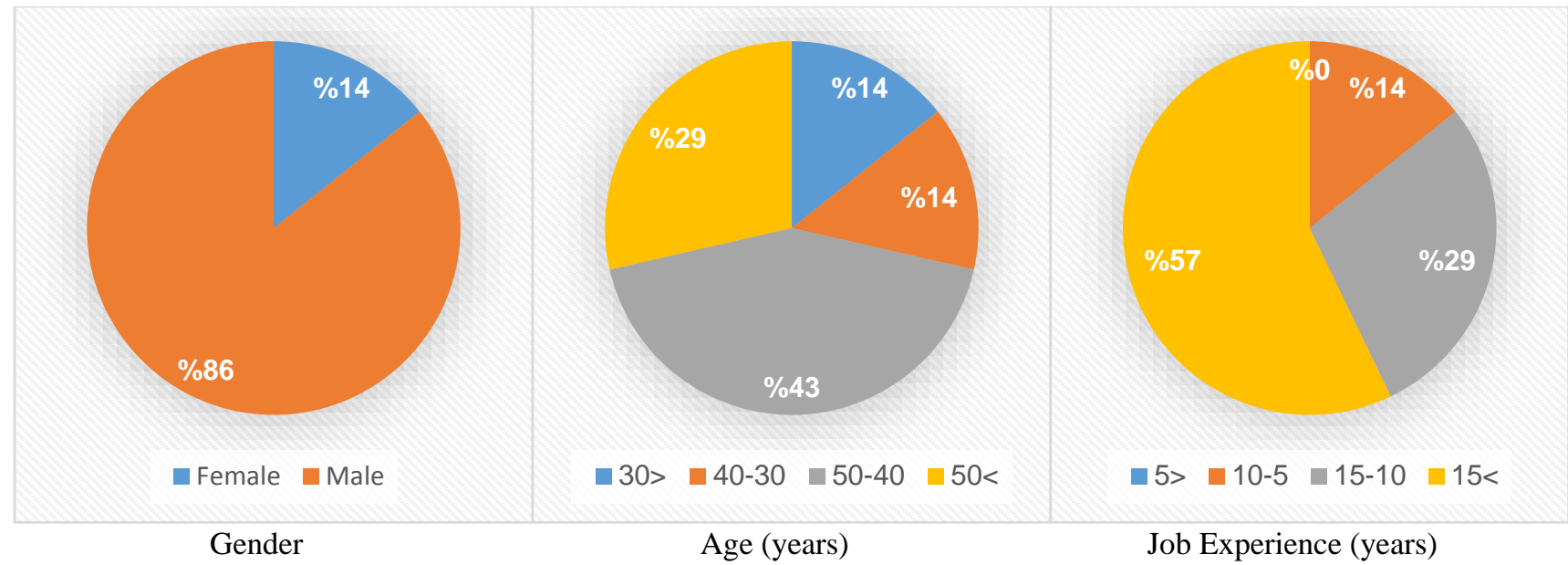

Fig. 1. Personal characteristics of the surveyed managers

(The figure shows the percentage of managers in each category)

In the second step, 29 green house managers, 22 managers from flower export companies, and 27 managers from flower distribution companies were asked to rank these seven barriers from the most important to the least important.

Friedman test was performed in order to rank the results and make sure that there is a difference between the seven barriers. According to chi-square table the benchmark value for chi-square for $\mathrm{df}=6$ and alpha $=0.05$ is equal to 12.59 . The chi-square which was calculated with the formula (i.e. test statistic) was equal to 14.08. Since the calculated chi-square (i.e. test statistic) was higher than the initial benchmark value for chi-square, it was concluded that null hypothesis should be rejected. In other words, it was concluded that there is a significant difference between the seven barriers at 95 percent confidence level. Table 1 summarizes the data obtained from Friedman test.

\section{Table 1}

Data from Friedman test

\begin{tabular}{cc}
\hline N (Number of Managers) & 78 \\
K (Number of Barriers) & 7 \\
DF (Degrees of Freedom) & 6 \\
alpha & 0.05 \\
\hline Benchmark Value for Chi-Square & 12.59 \\
Calculated Chi-Square (Test Statistic) & 14.08 \\
\hline Decision: Reject null hypothesis & \\
\hline
\end{tabular}

The final ranking of the 7 barriers based on the responses of these 78 managers was:

(1 indicates the most important barrier and 7 indicates the least important barrier)

1) Lack of investment in Iranian flower distribution sector. 
2) Rules limiting the presence of international distributors in Iranian flower industry.

3) Lack of technology for scheduling cut flower and raw material distribution.

4) Tariff barriers contributing to higher costs for raw material imports and distribution.

5) Using traditional methods for distributing cut flowers and raw materials.

6) Lack of scientific collaboration between trading partners'.

7) Insufficient integration of supply chain management technologies.

Fig. 2 shows the personal characteristics of these 78 managers.

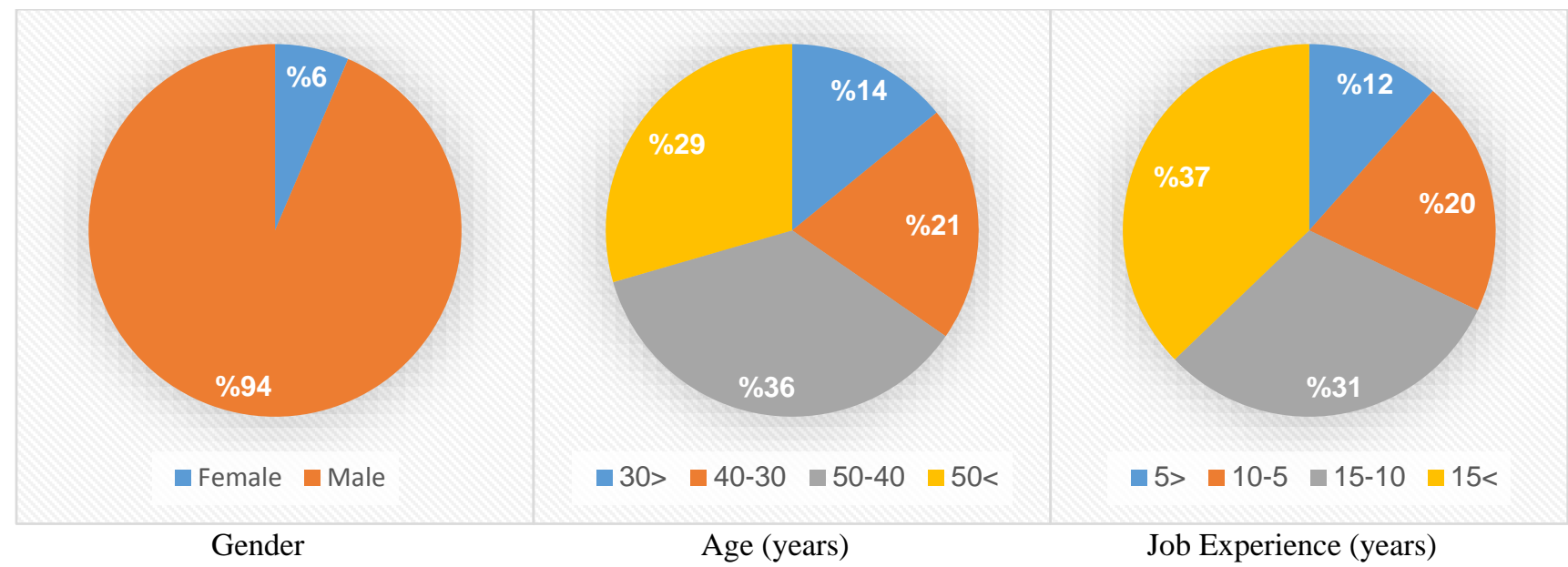

Fig. 2. Personal characteristics of the questionnaire respondents

(The figure shows the percentage of managers in each category)

Each of these 78 managers was also asked to answer a questionnaire. The questionnaire included 14 questions and its validity and reliability were approved after examining its content validity and calculating its Cronbach's alpha. The questionnaire's Cronbach's alpha was 0.8, indicating suitable internal consistency and reliability. The content validity of the questionnaire was also approved by 6 faculty members. Responses to the questionnaire's questions were used to accept or reject the following three hypotheses:

1) Allowing international distributors to enter Iranian flower industry's supply chain helps to immediately resolve the barriers to international supply chain management in this industry.

2) An increase in foreign investment will boost the introduction of modern scheduling technology and supply chain management methods to Iranian flower industry.

3) Resolving tariff barriers will help foreign distributors to monopolize Iranian flower industry supply chain.

To accept or reject the research's hypotheses, one-sample t-test was conducted with the use of SPSS software. Before performing the t-test, Kolmogorov-Smirnov test (KS test) was done in order to make sure that the data were normally distributed. For this test, the confidence level was set at 95 percent. According to KS test results the $\mathrm{P}$ for our data was equal to 0.67 . Since $\mathrm{P}=0.67$ is higher than 0.05 , the null hypothesis was accepted and it was concluded that our data followed a normal distribution with mean=3.2015E-02 and standard deviation=1.086.

\section{Results and Discussion}

After conducting one-sample t-test the following results were obtained: 
1) Allowing international distributors to enter Iranian flower industry's supply chain would not help to immediately resolve the barriers to international supply chain management in this industry. (95\% confidence level)

2) An increase in foreign investment will boost the introduction of modern scheduling technology and supply chain management methods to Iranian flower industry. (95\% confidence level)

3) Resolving tariff barriers will help foreign distributors to monopolize Iranian flower industry supply chain. (95\% confidence level)

The results indicate that although managers believed that lack of investment in Iranian flower distribution sector is the most important barrier to international supply chain management in Iranian flower industry, but they do not believe that international distributors will be able to resolve all of the current barriers to this sector in a short period. The respondents also believed that more foreign investment in Iranian flower industry helps Iranian flower exporters to use modern methods and technologies to have more effective international supply chain management. The questionnaires' results also indicated that resolving current tariff barriers will help foreign flower distributors to monopolize Iranian flower industry supply chains and dominate the transportation sector of this industry. This domination might enervate Iranian flower distributors and lower their chances for growth.

\section{Conclusion}

Among the main barriers to international supply chain management in Iranian flower industry, lack of investment in distribution sector has the highest priority for being resolved. It is important to allow foreign investors to invest in this sector in order to improve efficiency of supply chains and to ease the introduction of modern technologies and methods to this sector. An efficient international supply chain management can help Iranian flower producers to expand their exports and access high quality raw materials at a lower cost.

\section{References}

Amiri Aghdaie, S. F., Seidi, M., \& Riasi, A. (2012). Identifying the Barriers to Iran’s Saffron Export by Using Porter’s Diamond Model. International Journal of Marketing Studies, 4(5), 129-138. doi:10.5539/ijms.v4n5p129

Cervantes-Godoy, D., \& Dewbre, J. (2010). Economic Importance of Agriculture for Poverty Reduction, OECD Publishing.

Christiaensen, L., \& Demery, L. (2007). Down to earth: Agriculture and poverty reduction in Africa, World Bank Publications.

Eicher, C. K., \& Staatz, J. M. (1998). International agricultural development, JHU Press.

Forghaani, H., \& Kiaani Abari, M. (2005). Comparative advantage in manufacturing and exporting flowers and ornamental plants in selected provinces. Journal of humanities and social sciences, (19), 53-64.

Handfield, R. (2011). What is Supply Chain Management? Retrieved from http://scm.ncsu.edu/scmarticles/article/what-is-supply-chain-management

Hosseini, M. H., \& Hajishams, M. (2012). The investigation of defects in transport and packaging of exported cut flowers in Iran. Journal of research in agricultural science, 8(1), 93-99.

Karimi, M. R., \& Salehi, R. (1997). Marketing Barriers against flower imports to Iran. Iranian journal of International Marketing and consumer psychology, 7(3), 286-298.

Khojaste Nejad, A. (2011). Studying the difficulties of flower and plants producers in Iran and giving solutions. Retrieved from http://msc90.blogfa.com/post-11.aspx

Leonidou, L. C. (1995). Export barriers: non-exporters' perceptions. International Marketing Review, 12(1), 4-25.

Lequiller, F., \& Blades, D. (2006). Understanding National Accounts. Paris: OECD. 
Ligon, E., \& Sadoulet, E. (2007). Estimating the effects of aggregate agricultural growth on the distribution of expenditures. Available at SSRN 1769944.

McCalla, A. F., \& Nash, J. (2007). Reforming Agricultural Trade for Developing Countries: Key issues for a pro-development outcome of the Doha Round negotiations, World Bank Publications.

Mellor, J. W., \& Ranade, C. (2002). The impact of agricultural growth on employment in Rwanda: a three-sector model. Agricultural Policy Development Project-Research Report No, 14.

Mohamadi, A. (2001). Relationship between internet marketing and foreign direct investment on Iran's food industry. West Asian Journal of Marketing Management and Business Management, 3(4), 76-89.

Montalvo, J. G., \& Ravallion, M. (2010). The pattern of growth and poverty reduction in China. Journal of Comparative Economics, 38(1), 2-16.

Razaeii, M. (2012). Identifying Iran's agricultural products global target markets and their potential international rivals. Iranian Academy of Executive Studies Journal, 3(5), 39-48.

Riasi, A., \& Amiri Aghdaie, S. F. (2013). Effects of a Hypothetical Iranian Accession to the World Trade Organization on Iran's Flower Industry. Consilience: The Journal of Sustainable Development, 10(1), 99-110.

Yaghoubi, M. S., \& Mohamad Rezayi, A. (2007). Effective ways to expand exports of Iranian agricultural products: with focus on ornamental flowers export. Iranian journal of agribusiness, 2(2), 30-36.

Zamanian, A. R. (2010). Analysis of production and export marketing of flower and plants in Iran and providing effective strategies using marketing mix model: a case study of Mazandaran province. Commercial Surveys Journal, (39), 32-48. 